\title{
Uvaria botryoides (Annonaceae), a new species from Angola
}

\author{
Jorge Paiva ${ }^{1} \&$ Sara Bárrios² (ID
}

Summary. Uvaria botryoides Paiva, a new species from Angola is described and illustrated. The species distribution is mapped, and its conservation status assessed. It is compared to all species of the genus Uvaria that occur in Angola and a key to Angolan species is presented.

Key Words. Data Deficient, endemic, new taxa, red list, tribe Uvariae.

\begin{abstract}
Introduction
Annonaceae is a pantropical family with c. 42 genera and 400 species in Africa (Couvreur 2014; Chatrou et al. 2012; Couvreur et al. 2012). Uvaria L. is a genus belonging to the tribe Uvariae (Chatrou et al. 2012) with just over 100 species (Verdcourt 1971) found throughout tropical and subtropical regions of the Old World. This genus has c. 55 species in Africa, 14 of which occur in Angola. In Figueiredo \& Smith's Angolan Checklist, Paiva (2008) initially recognised 11 species of Uvaria. Subsequently, two species of Uvariastrum Engl., Uvaria modesta (Diels) Couvreur and Uvaria paivana Couvreur, were transferred to Uvaria by Couvreur (2014) following his narrowing of the delimitation of Uvariastrum. Uvaria botryoides Paiva, described here, brings the total to 14 species of this genus occurring in Angola. Of these, the following six species are endemic to Angola: $U$. botryoides Paiva, U. cabindensis Exell, U. cuanzensis Paiva, U. johannis Exell, U. mendesii Paiva, U. paivana Couvreur.
\end{abstract}

\section{Taxonomic Account}

Uvaria botryoides Paiva sp. nov. Type: Angola, Cuanza Sul, Bimbe-Cachoeiras road, 22 km from Cachoeiras, fl., 25 April 1967, Teixeira et al. 11507 (holotype COI [COI00072625]; isotype LISC).

http://www.ipni.org/urn:lsid:ipni.org:names:77194122-1

Straggling or scandent shrub up to $2 \mathrm{~m}$; young branches rusty stellate-pubescent, later glabrescent or glabrous, prominent lenticellate. Leaves petiolate, petiole (2 -) 3 - $4 \mathrm{~mm}$ long, canaliculate, stellatepubescent, later glabrescent; leaf-blades elliptic-ob- long or obovate-oblong, $(3-) 6-10(-11.5) \times(1.5-) 2$ $-3.5(-4) \mathrm{cm}$, apex acute, base cuneate or rounded, coriaceous, discolorous, glabrous above, sparse stellate-pubescent or almost glabrous, beneath; nerves impressed and glabrous above, prominent and stellatepubescent beneath, lateral nerves $6-20$ (- 23), somewhat prominent, venation rather prominent beneath. Flowers solitary, extra-axillary, pedicellate, pedicels $1-1.5 \mathrm{~cm}$ long, ferruginous stellatepubescent; bracteoles ovate, $4-5 \times 3-4 \mathrm{~mm}$, sessile, sparse stellate-pubescent, later deciduous. Calyx cupular in bud, with a small triangular opening at the apex, splitting irregularly into 3 ovate lobes, $3.5-4 \times 4$ $\mathrm{mm}$, at anthesis, ferruginous stellate-pubescent on both surfaces. Petals 5 yellow, fleshy, subequal, ovateelliptic, $8-10 \times 5-7 \mathrm{~mm}$, rounded at the apex, densely stellate-tomentose on both surfaces. Stamens $70-80$, linear, c. $1.5 \mathrm{~mm}$ long, connective-prolongation capitate, glabrous. Carpels $12-15$, cylindric, yellow, $1.5 \mathrm{~mm}$ long, glabrous; stigma verrucous, pilose. Fruiting pedicels, $1.5-2 \mathrm{~cm}$ long, verrucous, glabrous; monocarps stipitate, ellipsoid, $1.5-1.8 \times 1-1.2 \mathrm{~cm}$, 1 - 4-seeded, scarcely constricted between the seeds, obtuse, yellow verrucose, glabrous; stipes $1-1.5 \mathrm{~cm}$ long. Seeds ellipsoid, $8-9 \times 4 \mathrm{~mm}$. Fig. 1 .

RECOGNITION. This species belongs to a complex, in which the species, Uvaria angolensis Oliv., U. botryoides, $U$. cuanzensis, $U$. lucida Benth. and $U$. versicolor Pierre ex Engl. \& Diels are not easy to distinguish without flowers. Uvaria botryoides is the only one with a pubescent stigma.

DISTRIBUTION. Endemic to Angola. Map 1.

SPECIMENS EXAMINED. Angola. Cuanza Sul: BimbeCachoeiras road, $22 \mathrm{~km}$ from Cachoeiras, fl., 25 April

\footnotetext{
Accepted for publication 22 January 2019. Published online 15 March 2019

1 Centre for Functional Ecology, Department of Life Sciences, University of Coimbra, Calçada Martin de Freitas, 3000-456, Coimbra, Portugal. e-mail: jaropa@bot.uc.pt

2 Royal Botanic Gardens, Kew, Richmond, Surrey, TW9 3AE, UK.
} 


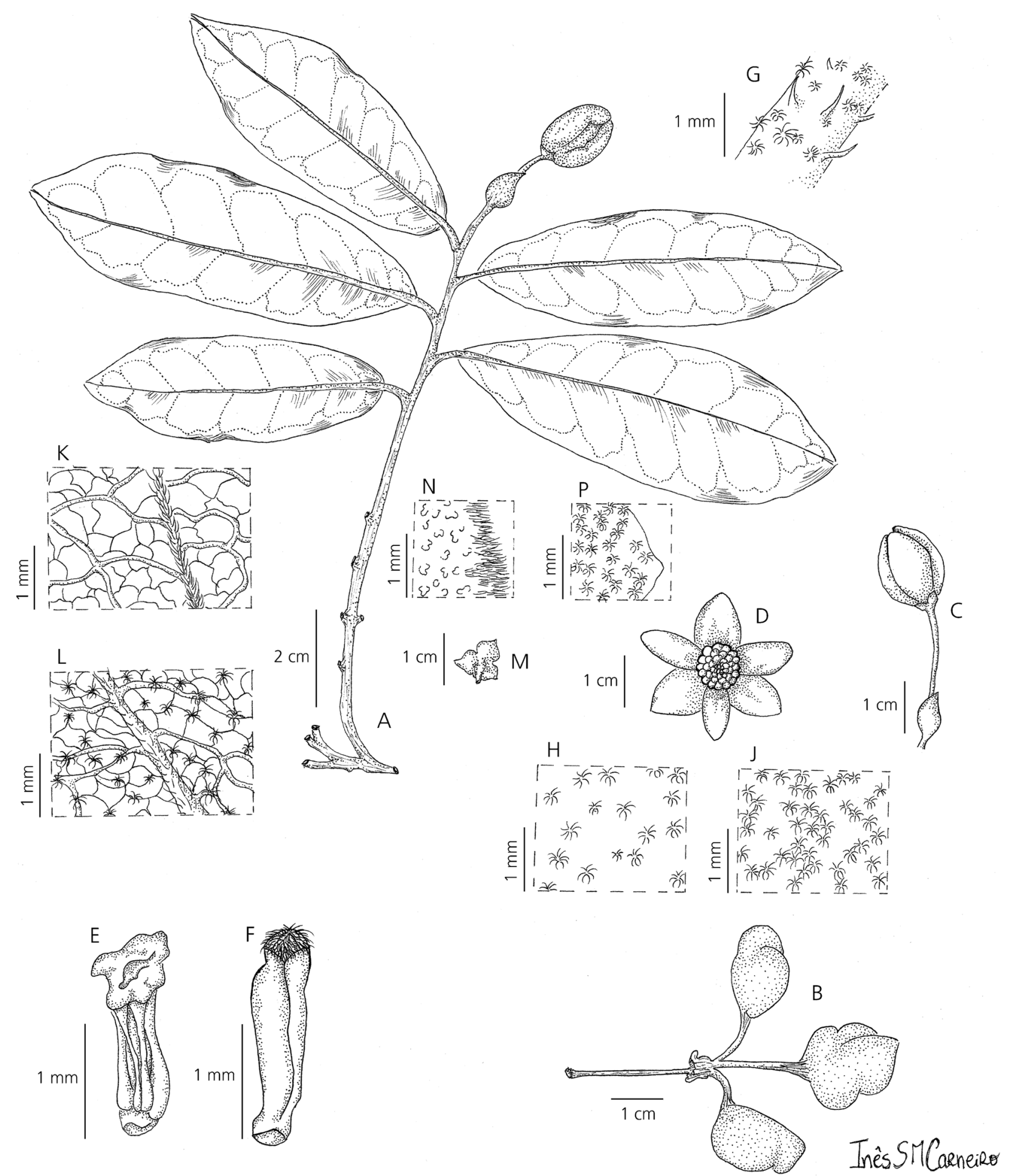

Fig. 1. Uvaria botryoides. A habit; B fruit; C bud; D flower; E stamen; F carpel; G detail of pubescence on the pedicel surface; $\mathrm{H}$ detail from undersurface of petal; $J$ detail from upper surface of petal; $K$ detail from upper surface of leaf; $L$ detail from undersurface of leaf; $\mathbf{M}$ calyx; $\mathbf{N}$ detail from upper (inner) surface of sepal; P detail from under (external) surface of sepal. DRAWN BY INÊS S. M. CARNEIRO.

1967, Teixeira et al. 11507 (holotype COI [COI00072625]; isotype LISC); Entre a Fazenda Cambongo e Muxixe na região da Munenga, $400 \mathrm{~m}$ alt. [Cuanza Sul: Munenga region, between Cambongo Farm and Muxixe, $400 \mathrm{~m}$. alt.], fr., 22 Jan. 1971, Raimundo, Matos E F Figueira 812 (paratype LISC!). 


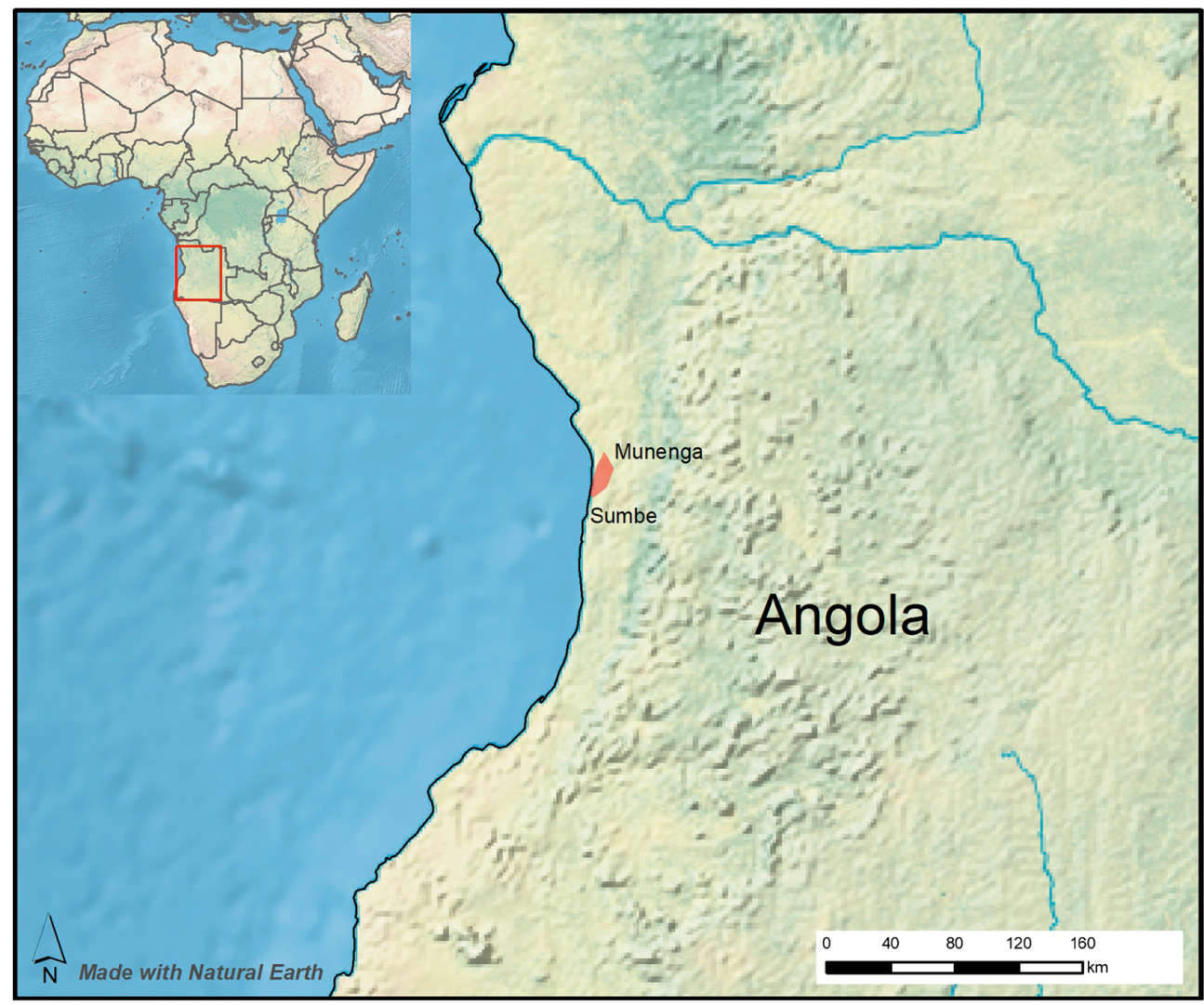

Map 1. Distribution of Uvaria botryoides Paiva based on known localities (G. Matos pers. comm. 2016).

HABITAT. Secondary and rain forest, thickets and forest edges.

CONSERVATION STATUS. This species is described here from only two herbarium collections. Despite good locality information provided on the labels, both collections are approximately 50 years old and little is known about the current distribution of this species. There are not enough point data to calculate extent of occurrence (EOO). The area of occupancy (AOO) is only $8 \mathrm{~km}^{2}$ but this is most likely a minimum AOO value. There is a lack of information on the size of populations and number of mature individuals. It is suspected that subsistence agriculture and charcoal production are slowly destroying native forests in the proximity of the area previously known as Novo Redondo as well as in the region of Munenga. This species is probably present in areas where the terrain makes farming difficult to establish, nearer Munenga and Calulo and more in the south-east, near Bimbe (Matos, G. pers. comm. 2016). Surveys in these regions are needed to fully document the distribution and the size of the population of this species, as well as any threats. As a result, according to IUCN categories and criteria (2012), this species is assessed as Data Deficient (DD).

NOTES. The sister taxa to the species described all have distinctive characters. Uvaria cuanzensis and $U$. versicolor are species with the connective protuberance densely patent pubescent, but the former has leaves completely glabrous, while $U$. versicolor has leaves with stellate hairs below, at least on the main nerve. The remaining two, $U$. angolensis and $U$. lucida, are not a problem to identify in Angola, because the latter does not occur in the country. The former has leaves with rather coarse indumentum and lateral nerves and venation impressed above, while the leaves of $U$. lucida are glabrescent or with fine indumentum and the lateral nerves almost not impressed and venation slightly raised. The 14 species which occur in Angola can be identified by the following key:

\section{Key to Uvaria species in Angola}

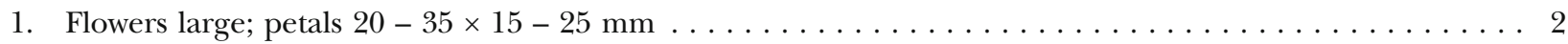

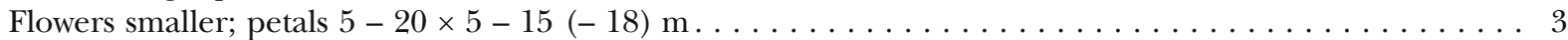

2. Petals oblong-ovate, acuminate; monocarps cylindric, $15-30 \times 5-12 \mathrm{~mm}$, apiculate $\ldots \ldots \ldots \ldots$ U. osmantha Petals obovate-suborbicular, rounded at the apex; monocarps ellipsoid, $30-35 \times 12-15 \mathrm{~mm}$, rounded at the

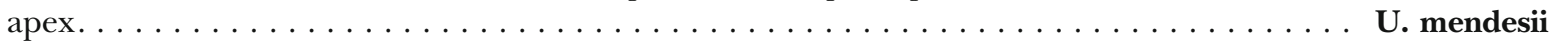


3. Leaf blade scabrid above; monocarps contiguous, sessile or very shortly stipitate . . . . . . . . . U. scabrida Leaf blade smooth above; monocarps, separated, stipitate $\ldots \ldots \ldots \ldots \ldots \ldots$

4. Monocarps globose or broadly ovoid, stipes at least twice as long as the monocarps . . . . . . . . 5 Monocarps ellipsoid or cylindric, stipes shorter than twice as long as the monocarps . . . . . . . 7

5. Leaf blade, coriaceous or subcoriaceous, concolorous, glabrous to glabrescent; monocarp stipes $3-5 \mathrm{~cm}$

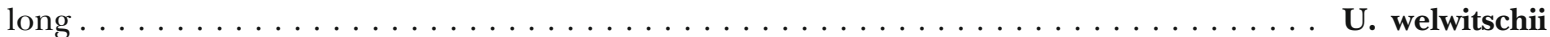
Leaf blade papyraceous or membranaceous, discolorous, stellate-pubescent; monocarp stipes $2-3.5 \mathrm{~cm}$

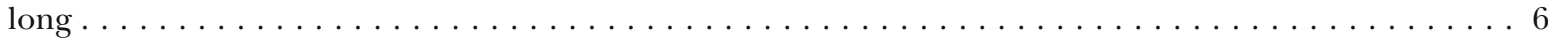

6. Monocarps long stipitate, stipes $2-3.5 \mathrm{~cm}$ long; petals coriaceous, revolute . . . . . . . . . . U. poggei Monocarps shorter stipitate, stipes c. 2 cm long; petals fleshy, not revolute . . . . . . . . . . U. cabindensis

7. Leaf blade glabrous; connective protuberance densely patent pubescent. . . . . . . . . . . . . U. cuanzensis Leaf blade pubescent, at least on the lower side of midrib; connective protuberance glabrous . . . . . 8

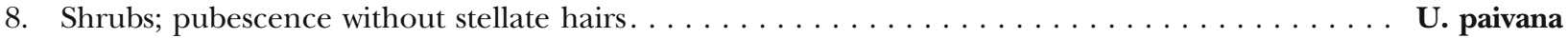
Lianas or shrubs; pubescence with stellate hairs $\ldots \ldots \ldots \ldots \ldots \ldots$

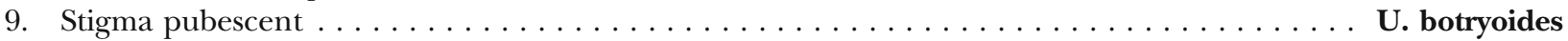

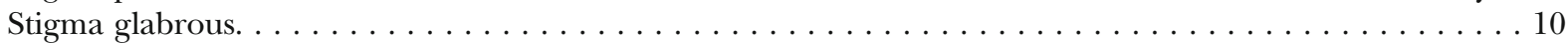

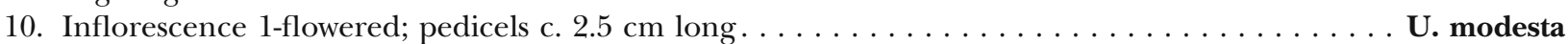
Inflorescence $1-4$-flowered; pedicels up to $5-6 \mathrm{~mm}$ long $\ldots \ldots \ldots \ldots$

11. Calyx with lobes distinct in bud, separating into regular sepals at anthesis, free to the middle or to the

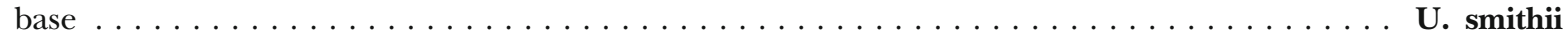
Calyx cupular in bud, splitting \pm irregularly into three lobes at anthesis or remaining scarcely lobed . . . . . 12

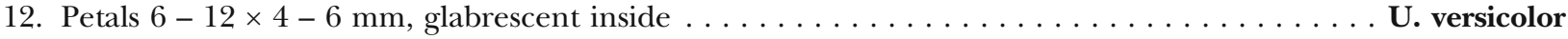

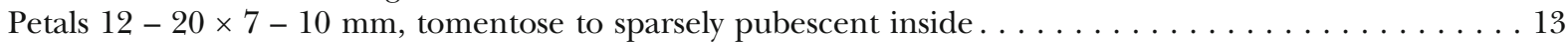

13 Leaf blade up to $24 \times 8 \mathrm{~cm}$, long acuminate, papyraceous; connective protuberance $0.3-0.5 \mathrm{~mm}$ long . . U. johannis Leaf blade up to $13(-16) \times 6(-8) \mathrm{cm}$, acuminate or rounded, coriaceous or subcoriaceous; connective protuberance $1 \mathrm{~mm} \operatorname{long} \ldots \ldots \ldots \ldots \ldots \ldots \ldots \ldots \ldots \ldots \ldots$ angolensis

\section{Acknowledgements}

The authors would like to thank Dr Fernanda Lages (ISCED, Lubango, Angola) and Eng. Gilberto Cardoso de Matos, who collected in Angola for several years, until 1975 , and provided information about the distribution and threats of this species. Thanks to Inês S. M. Carneiro for the excellent drawing. The authors also wish to thank the two reviewers who made very useful comments on an earlier version of the manuscript.

Open Access This article is distributed under the terms of the Creative Commons Attribution 4.0 International License (http://creativecommons.org/ licenses/by/4.0/), which permits unrestricted use, distribution, and reproduction in any medium, provided you give appropriate credit to the original author(s) and the source, provide a link to the Creative Commons license, and indicate if changes were made.

\section{Publisher's Note}

Springer Nature remains neutral with regard to jurisdictional claims in published maps and institutional affiliations.

\section{References}

Chatrou, L. W., Pirie, M. D., Erkens, R. H. J., Couvreur, T. L. P., Neubig, K. M., Abbott, R. J., Mols, J. B., Maas, J. W., Saunders, R. M. K. \& Chase, M. W. (2012). A new higher-level classification of the pantropical flowering plant family Annonaceae informed by molecular phylogenetics. Bot. J. Linn. Soc. 169: $5-40$.

Couvreur, T. L. P. (2014). Revision of the African genus Uvariastrum (Annonaceae). PhytoKeys 33: 1 40.

, Maas, P. J. M., Meinke, S., Johnson, D. M. \& Keßler, P. J. A. (2012). Keys to the genera of Annonaceae. Bot. J. Linn. Soc. 169: $74-83$.

IUCN (2012). IUCN Red List Categories and Criteria: Version 3.1. Second edition. Gland and Cambridge. http:/ / www.iucnredlist.org/technical-documents/ categories-and-criteria.

Paiva, J. A. R. (2008). Annonaceae. In: E. Figueiredo \& G. P. Smith (eds), Plants of Angola. Strelitzia 22: 29 32.

Verdcourt, B. (1971). Annonaceae. In: E. MilneRedhead \& R. M. Polhill (eds), Flora of Tropical East Africa. Crown Agents, London. 